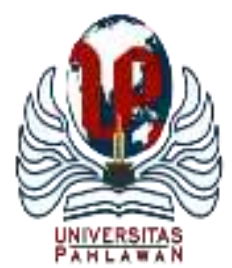

\title{
JURNALBASICEDU
}

Volume 5 Nomor 6 Tahun 2021 Halaman 5100 - 5111

Research \&Learningin Elementary Education

https://jbasic.org/index.php/basicedu

\section{Pengembangan Media Pembelajaran Berbasis Komik untuk Meningkatkan Karakter Kemandirian Belajar Siswa Sekolah Dasar}

\author{
Susetyo Andri Wibowo ${ }^{1 凶}$, Henny Dewi Koeswanti ${ }^{2}$ \\ Program Studi Pendidikan Guru Sekolah Dasar, Universitas Kristen Satya Wacana, Indonesia ${ }^{1,2}$ \\ E-mail: $\underline{\text { aw14846@gmail.com }}{ }^{1}$, henny.koeswanti@uksw.edu ${ }^{2}$
}

\begin{abstract}
Abstrak
Salah satu upaya untuk menanamkan pendidikan karakter belajar kepada siswa dapat diimplementasikan melalui media pembelajaran. Media pembelajaran yang menarik akan mempermudah siswa dalam memahami materi, media pembelajaran yang didesain sangat menarik akan membuat siswa tidak mudah bosan dan siswa dapat termotivasi untuk semangat di dalam belajar. Tujuan pengembangan penelitian ini untuk menghasilkan sebuah produk berupa media pembelajaran dengan sebuah komik tentang sikap kemandirian anak dalam belajar untuk siswa kelas 3 SD. Penelitian yang akan dilakukan ini merupakan jenis penelitian dan pengembangan atau Research and Development (R \& D). Untuk mengukur tingkat kelayakan produk komik tersebut maka dapat dilakukan tahap validasi dari uji media, uji materi dan uji validasi bahasa.Teknik analisis data pada penelitian ini menggunakan teknik deskriptif. Hasil penelitian menunjukan bahwa media komik untuk meningkatkan katakter belajar siswa kelas 3 SD sangat layak digunakan. Dibuktikan dengan hasil uji validasi ahli media pembelajaran dengan nilai $75 \%$ yang termasuk dalam kategori tinggi, penilaian materi pembelajaran dengan nilai $71 \%$ dengan kategori tinggi dan penilaian bahasa pembelajaran dengan nilai $75 \%$ yang termasuk dalam kategori tinggi.
\end{abstract}

.Kata Kunci: Komik, Karakter kemandirian belajar

\begin{abstract}
One of the efforts to instill character education in students can be implemented through learning media. Interesting learning media will make it easier for students to understand the material, learning media that are designed very attractively will make students not easily bored and students can be motivated to be enthusiastic in learning. One method is to use learning media through comics. The research that will be carried out is a type of research and development or Research and Development $(R \& D)$. The product that will be produced in this research is a comic-based learning media for independent character education for grade 3 elementary school students. To measure the level of feasibility of the comic product, the validation phase of the media test, material test and validation test by 3rd grade elementary school teachers can be carried out. The data analysis technique is expert validation test using a descriptive qualitative percentage technique. The results showed that the comic media to improve the learning character of 3rd grade elementary school students was very feasible to use. It is proven by the results of the expert validation test of learning media with a score of $75 \%$ which is included in the high category, the assessment of learning materials with a value of $71 \%$ in the high category and the assessment of learning language with a value of $75 \%$ which is included in the high category.
\end{abstract}

Keywords: Comics, independent learning character

Copyright (c) 2021 Susetyo Andri Wibowo, Henny Dewi Koeswanti

$\triangle$ Corresponding author :

Email : aw14846@gmail.com
DOI $:$ https://doi.org/10.31004/basicedu.v5i6.1600
PENDAHULUAN

ISSN 2580-3735 (Media Cetak)

ISSN 2580-1147 (Media Online)

PENDAHULUAN 
5102 Pengembangan Media Pembelajaran Berbasis Komik untuk Meningkatkan Karakter kemandirian Belajar Siswa Sekolah Dasar- Susetyo Andri Wibowo, Henny Dewi Koeswanti

DOI: https://doi.org/10.31004/basicedu.v5i6.1600

Pendidikan berperan penting terhadap perkembangan diri manusia dan dipercayai dapat meningkatkan taraf hidup manusia. Pendidikan nasional menurut Sisdiknas. UU No. 20 (Yusutria \& Febriana, 2019) berfungsi untuk mengembangkan kemampuan dan membentuk manusia yang berkarakter untuk mencerdasakan bangsa. Selain pendidikan yang baik, karakter yang terbentuk dengan baik juga melatar belakangi manusia dalam mencapai tujuan hidupnya. Menurut Puskurbruk (dalam Putry, 2019) yang menelaah 18 nilai karakter yang berasal dari agama, pancasila, budaya, dan tujuan pendidikan nasional, antara lain: 1) religius, 2) jujur, 3) toleransi, 4) disiplin, 5) kerjakeras, 6) kreatif, 7) mandiri, 8) demokratis, 9) rasa keingin tahuan, 10) semangat kebangsaan, 11) cinta tanahair, 12) menghargai prestasi, 13) bersahabat, 14) cinta damai, 15) gemar membaca, 16) peduli lingkungan, 17) peduli sosial, 18) tanggung jawab. Sependapat dengan (Saputri, 2021) pendidikan karakter diperlukan oleh tiap manusia sebagai sarana pengembangan diri untuk menanamkan nilai-nilai luhur dalam kehidupan. Dengan adanya pendidikan setiap orang bisa mengembangkan setiap potensi yang dimiliki sehingga nantinya dapat digunakan sebagai bekal dalam menghadapi berbagai perubahan yang terjadi dalam kehidupan yang sebenarnya. Pendidikan karakter dibutuhkan sejak anak usia dini. Menurut (Lestari \& Mustika, 2021) pendidikan karakter merupakan salah satu kunci keberhasilan pendidikan di Indonesia. Karakter apabila sudah tertanam pada diri sesorang sejak usia dini dimaksudkan untuk menanamkan nilai-nilai kebaikan supaya dapat menjadi kebiasaan ketika kelak dewasa atau pada jenjang pendidikan selanjutnya (Cahyaningrum, 2017).

Menurut (Cahyaningrum, 2017) pendidikan karakter pada prinsipnya adalah upaya untuk menumbuhkan kepekaan dan tanggung jawab sosial, membangun kecerdasan emosional, dan mewujudkan siswa yang memiliki etika tinggi. Terbentuknya karakter yang baik dapat dilaksanakan dalam dunia pendidikan. Karena pendidikan pada dasarnya merupakan suatu fasilitas pembelajaran untuk keterampilan, mengembangkan pengetahuan, dan karakter manusia. Fungsi adanya pendidikan karakter adalah sebagai pengembangan potensi individu atau peserta didik agar menjadi pribadi yang berperilaku baik. Bertanggung jawab diajarkan dalam mengembangkan potensi dari individu yang dimiliki, dan pendidikan karakter berfungsi untuk menyaring budaya dari bangsa sendiri maupun budaya dari bangsa lain yang tidak sesuai dengan nilai-nilai budaya dan katakter bangsa sendiri. Oleh karena itu dalam peningkatan karakter pada diri setiap individu dibutuhkan peran dari berbagai elemen, seperti keluarga, sekolah, pemerintah maupun masyarakat setempat.

Satu dari sekian karakter yang perlu dimiliki setiap anak adalah karakter mandiri, sesuai dengan penelitian (Ariah, 2015) bahwa karakter yang saat ini dianggap lemah yaitu karakter kemandirian, dilihat dari banyaknya individu yang masih sering tergantung dengan orang lain terkait permasalahan hidupnya contohnya dalam belajar, banyak anak yang belum bisa mandiri dalam mengerjakan kewajibannya. Sehingga dengan karakter tersebut akan menciptakan individu yang unggul dan dapat memajukan bangsa. Seturut dengan pendapat (Nasution, 2018) kemandirian juga dapat di artikan sebagai "independence" yang diartikan sebagai suatu kondisi tidak bergantung terhadap orang lain dalam menentukan keputuan dan adanya sikap percaya diri. Mandiri merupakan sikap yang sudah langka di negeri Indonesia, banyak dijumpai permasalahan yang terjadi dan dialami oleh banyak orang. Lima indikator mandiri menurut Kemendikbud, yaitu kerja keras, kreatif, disiplin, berani, dan pembelajar (Marsiyah, 2020). Karakter mandiri sangat perlu ditanamkan karena berguna bagi kehiduopan setiap individu. Menurut pendapat Brewer (dalam Silawati, Taat Kurnita Yeniningsih, 2021) bahwa kemandirian anak memiliki indikator antara lain pembiasaan yang terdiri dari kemampuan fisik, percaya diri, bertanggung jawab, disiplin, pandai bergaul, mau berbagi, dan dapat mengendalikan emosi. Sesuai dengan Peraturan Presiden nomor 87 tahun 2017 mengenai acuan penyelenggaraan pendidikan karakter yang memuat gerakan pendidikan karakter (PPK).

Menurut Aini ( dalam Wuryandani et al., 2016) menjelaskan bahwa kemandirian belajar yaitu anak akan mampu belajar secara mandiri, tidak mudah bergantung dengan orang lain, percaya akan kemampuan dirinya .Hal ini disebabkan saat berada di lingkup sekolah maka siswa sudah sering atau akan dihadapkan pada 
5103 Pengembangan Media Pembelajaran Berbasis Komik untuk Meningkatkan Karakter kemandirian Belajar Siswa Sekolah Dasar- Susetyo Andri Wibowo, Henny Dewi Koeswanti

DOI: https://doi.org/10.31004/basicedu.v5i6.1600

permasalahan yang mengajak siswa untuk hidup secara mandiri. Sejalan dengan penelitian (Rahmayani, 2019) bahwa mandiri belajar merupakan hal yang sangatlah penting dalam proses pembelajaran karena mandiri dalam proses belajar akan berpengaruh pada prestasi belajar siswa nantinya. Kemandirian dapat berkembang secara bertahap melalui proses pembelajaran yang telah dilakukan dilakukan secara bertahap. Dengan begini guru merupakan pelaksana pendidikan di lingkup sekolah, sehingga guru harus dapat menciptakan atau mengembangkan sebuah pembelajaran yang klasik menjadi sebuah pembelajaran yang menarik terutama dalam penanaman pendidikan karakter di sekolah (Khairi, 2016).

Salah satu upaya untuk menanamkan pendidikan karakter belajar kepada siswa dapat di implementasikan melalui media pembelajaran. Media pembelajaran menurut (Herliana \& Anugraheni, 2020) yaitu sebuah alat yang digunakan untuk menyalurkan pesan kepada siswa guna mengefektifkan komunikasi antara guru dan siswa dalam pembelajaran, sehingga dengan adanya media pembelajaran guru akan lebih mudah dalam menyampaikan isi pembelajaran. Media yang menarik akan mempermudah siswa dalam memahami materi, media pembelajaran yang didesain sangat menarik akan membuat siswa tidak mudah bosan dan siswa dapat termotivasi untuk semangat di dalam belajar. Maka dari itu pemilihan media yang tepat akan menciptakan kualitas pendidikan yang lebih baik lagi dan sebagai proses pembelajaran yang efektik.

Media pembelajaran yang disusun secara menarik dapat digunakan dalam proses pembelajaran salah satunya adalah komik, yang dimana masih banyak anak sampai orang dewasa pun masih sangat gemar membaca komik. Media pembelajaran komik dapat dikatakan menarik dikarenakan komik tersususn dari beberapa alur cerita yang dapat berfungsi untuk menarik perhatian pembacanya ataupun dilengkapi dengan banyak gambar dari pada tulisan sehingga penanggulang rasa bosan pada anak ketika membaca. Sependapat dengan Sudjana dan Rivai (dalam Suwarti et al., 2020) komik merupakan suatu bentuk seni yang menggunakan gambar-gambar tidak bergerak yang disusun sedemikian rupa sehingga membentuk jalinan cerita.

Komik juga memiliki beberapa karakteristik, di antaranya menurut Sudjana \& Rivai(dalam Subroto et al., 2020): (a) komik biasanya terdiri dari berbagai situasi cerita yang bersambung; (b) bersifat menghibur; (c) komik memiliki perwatakan lain, biasanya dikenal agar kekuatan komik dapat dihayati; (d) komik memusatkan perhatian di lingkungan sekitar rakyat; (e) pembaca dapat dengan segera mengidentifikasi dirinya melalui perasaan serta tindakan dari perwatakan tokoh utama karena cerita pada komik mengenai diri pribadi; (f) cerita dalam komik ringkas dan menarik perhatian; (g) komik biasanya dilengkapi aksi; (h) pembuatannya lebih hidup dengan pemakaian warna utama secara bebasMelalui komik informasi juga akan tersalurkan kepada pembaca dengan jelas. Dengan adanya komik tentang kemandirian seseorang ini akan lebih menjelaskan gambaran nyata sikap yang harus dimiliki siswa dalam kehidupan sehari-hari terutama dalam hal belajar. Dalam media komik yang dikembangkan ini memiliki alur dimana seorang anak yang tidak bertanggung jawab dalam menjalankan kewajibannya belajar, dan anak tergantung kepada teman lainya serta percaya kepada kemapuan diri sendiri. Sehingga komik ini akan memberikan pembelajaran khusus kepada anak untuk mengembangkan karakter mandiri terutama dalam hal belajar. Seseorang akan belajar secara maksimal jika berkomunikasi atau berinteraksi dengan stimulus yang cocok dengan gaya belajarnya. Komik dapat berfungsi sebagai media pembelajaran komunikasi visual, dimana konteks pembelajaran dapat mengacu pada proses komunikasi antara siswa dan sumber belajar. Senada dengan pendapat Hurlock (dalam Fadillah, 2018) alasan anak senang dalam membaca komik salah satunya komik mudah dibaca serta anak yang memiliki kemampuan baca yang rendah dapat memahami isi dari komik karena melihat gambar yang ada dalam komik tersebut.

Berdasarkan hasil observasi kepada siswa kelas 3 SD N Mangunsari 07 Salatiga, untuk karakter kemandirian belajar pada siswa belum sepenuhnya terealisasi. Masih banyak siswa yang kurang mandiri kurang percaya diri dalam belajar. Seperti halnya dalam pengumpulan tugas masih ada beberapa siswa yang tidak mengumpulkan atau saat pembelajaran masih banyak siswa yang tidak memperhatikan, dalam ulangan 
juga terdapat siswa yang sering tanya kepada siswa lain. Sehingga tingkat percaya diri siswa sangat lemah. Berbagai cara sudah guru upayakan untuk meningkatkan kemandirian belajar siswa. Tetapi untuk perubahan belum terlihat sepenuhnya. Banyak anak yang sangat menyukai komik. Saat ini media untuk menunjang peningkatan karakter kemandirian belajar pada siswa masih jarang ditemukan. Peneliti berharap bahwa media komik ini dapat memikat siswa agar memiliki kemauan dalam membacanya. Media komik dipilih dengan berbagai pertimbangan seperti banyak anak yang masih gemar membaca komik, dari media komik dapat menyajikan gambaran cerita secara konkret dengan desain gambar dan percakapan yang menarik, dalam penggunaanyapun dapat digunakan dimana dan kapan saja.

Berdasarkan pernyataan yang sudah dipaparkan, peneliti ingin mengembangkan sebuah media yang dapat membantu siswa dalam meningkatkan karakter kemandirian pada diri anak melalui sebuah media pembelajaran komik. Media pembelajaran komik ini menawarkan beberapa kelebihan dimana cerita yang disajikan menyangkut kehidupan sehari-hari anak yang mengandung karakter kemandirian. Diharapkan dengan adanya sebuah media pembelajaran ini akan membuat siswa tertarik dalam membaca sehingga apa yang dituangkan dalam cerita komik dapat membantu peningkatan karakter kemandirian belajar siswa kelas 3 .

\section{METODE PENELITIAN}

Penelitian pada dasarnya merupakan kegiatan sistematis untuk dapat memcahkan masalah yang dapat dilakukan dengan cara menerapkan metode ilmiah. Penelitian yang akan dilakukan ini merupakan jenis penelitian dan pengembangan atau Research and Development ( $R$ \& D). Menurut (Sukmadinata, 2016) penelitian pengembangan merupakan penelitian yang bertujuan dapat menghasilkan produk baru atau dapat mengembangkan sebuah produk yang sudah ada serta dapat dipertanggungjawabkan. Produk yang akan dihasilkan dalam penelitian ini berupa media pembelajaran berbasis komik pendidikan karakter mandiri untuk siswa kelas 3 Sekolah Dasar. Untuk mengukur tingkat kelayakan produk komik tersebut maka dapat dilakukan tahap validasi dari uji media, uji materi dan uji validasi oleh guru kelas 3 SD. Teknik analisis data uji validasi ahli dengan menggunakan teknik deskriptif kualitatif persentase. Data yang diperoleh dari hasil uji validasi ahli muatan pendidikan karakter dan kebahasaan di presentase menggunakan rumus sebagai berikut :

$$
\mathrm{AP}=\frac{\text { Skor } A k t u a ;}{\text { Skor Ideal }} \times 100 \%
$$

Keterangan :

AP

: Angka presentase

Skor Aktual : Skor yang diberikan oleh uji dari validasi ahli.

Skor Ideal : Skor maksimal hasil kali dari jumlah item dan skor maksimum

Angka prosentase tersebut selanjutnya dikelompokkan menjadi lima kategori berikut ini:

Tabel 1. Kategori Uji Validasi Ahli

\begin{tabular}{lc}
\hline \multicolumn{1}{c}{ Nilai Interval } & Kategori \\
\hline $81-100 \%$ & Sangat tinggi \\
\hline $61-80 \%$ & Tinggi \\
\hline $41-60 \%$ & Cukup \\
\hline $21-40 \%$ & Rendah \\
\hline $1-20 \%$ & Sangat rendah \\
\hline
\end{tabular}

Berdasarkan pendapat (Mawardi, 2014)dimana hasil validasi dapat dinyatakan layak untuk dilanjutkan ke tahap uji coba apabila persentase minimal yaitu lebih dari sama dengan $61 \%$. 
5105 Pengembangan Media Pembelajaran Berbasis Komik untuk Meningkatkan Karakter kemandirian Belajar Siswa Sekolah Dasar- Susetyo Andri Wibowo, Henny Dewi Koeswanti

DOI: https://doi.org/10.31004/basicedu.v5i6.1600

\section{HASIL DAN PEMBAHASAN}

Hasil penelitian pengembangan komik untuk meningkatkan karakter kemandirian belajar siswa kelas 3 SD berikut tahapan yang dilaksanakan dalam penelitian ini: Tahap Pendefinisian (define) dilakukan sebagai tahapan awal dalam pengembangankomik untuk meningkatkan karakter kemandirian belajar siswa kelas $3 \mathrm{SD}$ dimana tahap ini dilaksanakan untuk menyesuaikan kebutuhan media yang sesuai dengan tahap perkembangan siswa di kelas rendah. Dalam tahap ini dilakukan beberapa langkah, yaitu analisis awal, analisis karakter siswa, analisis materi, dan menuliskan tujuan.

Analisis awal dimana pada langkah ini dilakukan observasi dan wawancara pada salah satu guru kelas 3 , yang menyatakan bahwa masih banyaknya siswa yang belum mampu mandiri dalam belajar. Kendala yang dihadapi oleh guru dalam meningkatkan karakter kemandirian belajarsaat ini karena saat pandemi Covid 19 siswa belajar dirumah sehingga kurangnya pengawasan dari guru, selain itu pengawasan dari orang tua yang kurang sehingga anak lebih mengutamakan untuk bermain. Guru sudah berupaya dalam proses pembentukan karakter kemandirian belajar siswa di sekolah tetapi selain itu masih minimnya fasilitas media pembelajaran terutama media karakter belajar siswayang kurang memadahi. Sehingga perlu dikembangkannya sebuah media pembelajaran yang dapat mendukungsiswa dalam meningkatkan karakter belajar.Analisis karakter siswa, dimana siswa di kelas rendah khususnya kelas 3 di SD Negeri Mangunsari 07 sangat antusias jika belajar melalui sebuah cerita yang dilengkapi dengan gambar yang menarik.

Langkah berikutnya ialah analisis materi dimana pendidikan karakter yang saat ini perlu ditekankan yaitu karakter kemandirian pada diri siswa, diketahui saat ini banyak siswa yang belum terbiasa mandiri dalam hal belajar dimana siswa harus diingatkan berkali-kali untuk dapat melaksanakan kewajibannya. Dengan adanya cerita yang mendukung sebuah kemandirian belajar anak maka akan memotivasi pembaca dan dapat mengimplementasikan dalam dunia nyata.

Menuliskan tujuan, dimana media yang dikembangkan ini diharapkan dapat memenuhi kebutuhan siswa untuk mengetahui dan mengimplementasikan sikap mandiri dalam belajar.Tahap Perancangan (Design) pada tahap ini peneliti memulai dari memilih tema, memilih tokoh dan watak, alur cerita serta ilustrasi yang menarik sehingga anak dapat terpukau karena membaca komik kemandirian belajar yang disusun ini. Pemilihan bahasa yang sesuai dengan bahasa siswa kelas rendah juga akan membantu dalam pemahaman isi komik kemandirian belajar tersebut.

Berikut tampilan Cover Komik. Cover awal dilengkapi dengan judul cerita, serta diberikan ilustrasi yang sesuai dengan karakter tokoh yang terdapat pada komik.

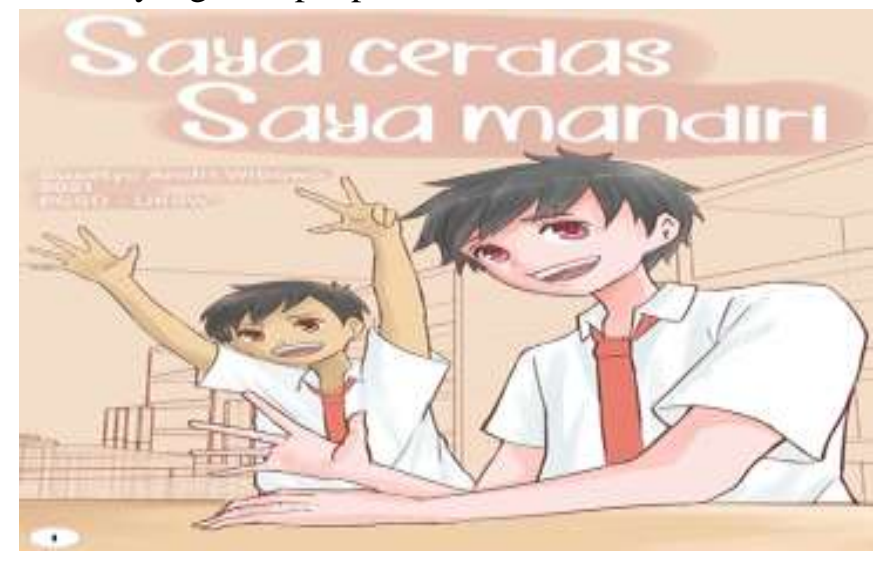

Gambar 1. Cover Komik

Tampilan Ilustrasi Alur Cerita Untuk meningkatkan kemandirian belajar sebagai berikut: 
5106 Pengembangan Media Pembelajaran Berbasis Komik untuk Meningkatkan Karakter kemandirian Belajar Siswa Sekolah Dasar-Susetyo Andri Wibowo, Henny Dewi Koeswanti

DOI: https://doi.org/10.31004/basicedu.v5i6.1600
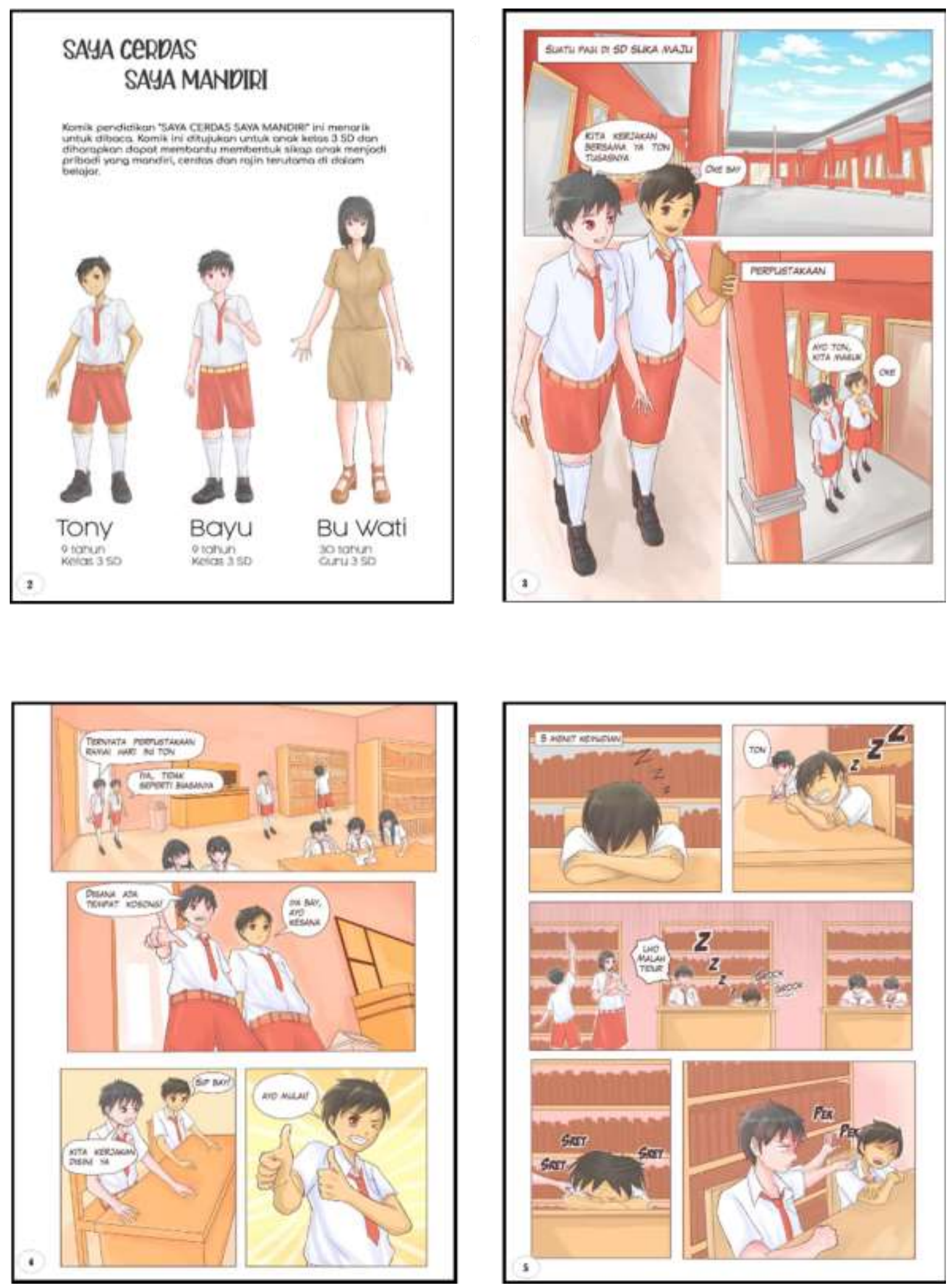
5107 Pengembangan Media Pembelajaran Berbasis Komik untuk Meningkatkan Karakter kemandirian Belajar Siswa Sekolah Dasar-Susetyo Andri Wibowo, Henny Dewi Koeswanti DOI: https://doi.org/10.31004/basicedu.v5i6.1600
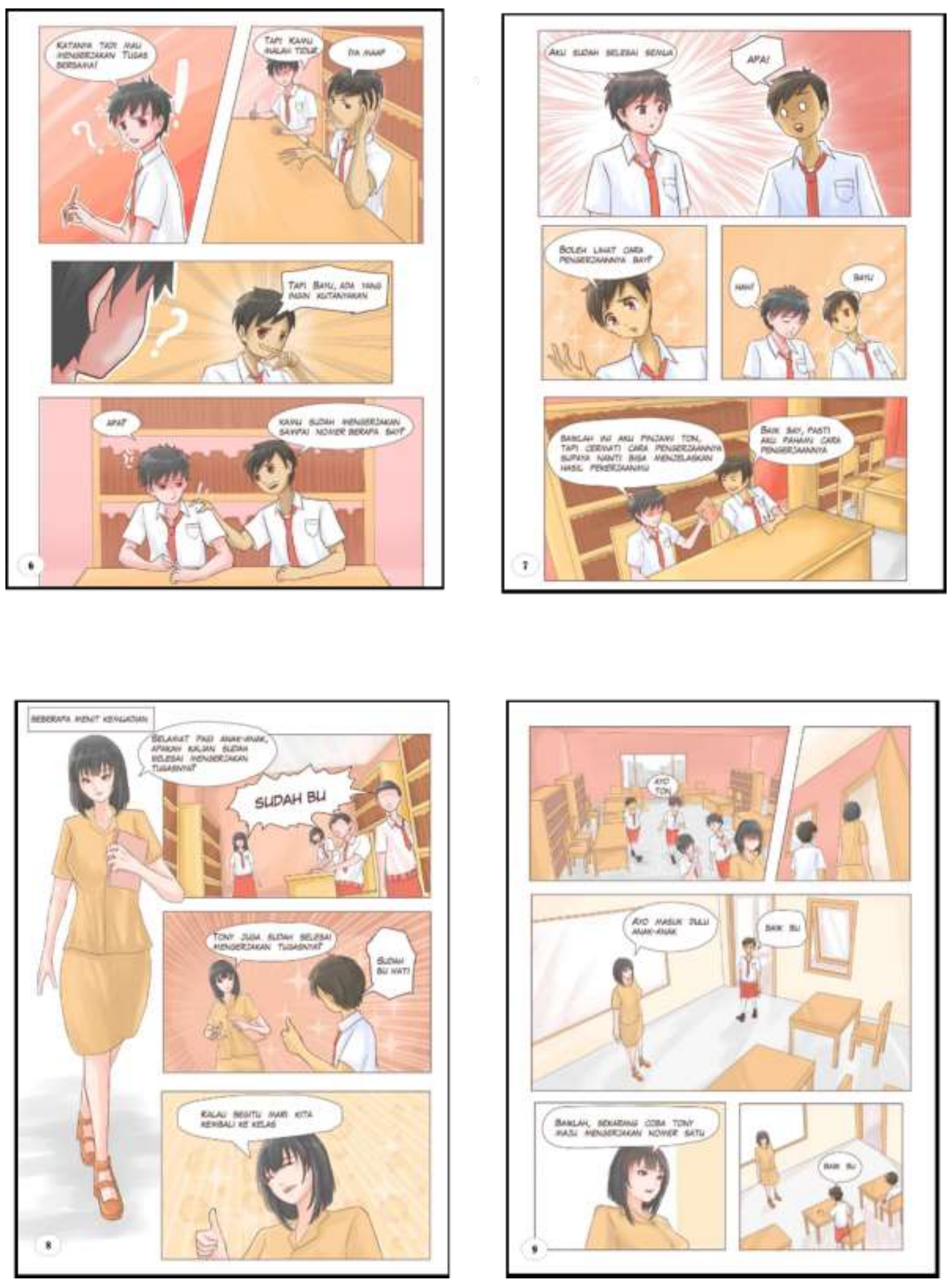
5108 Pengembangan Media Pembelajaran Berbasis Komik untuk Meningkatkan Karakter kemandirian Belajar Siswa Sekolah Dasar- Susetyo Andri Wibowo, Henny Dewi Koeswanti

DOI: https://doi.org/10.31004/basicedu.v5i6.1600
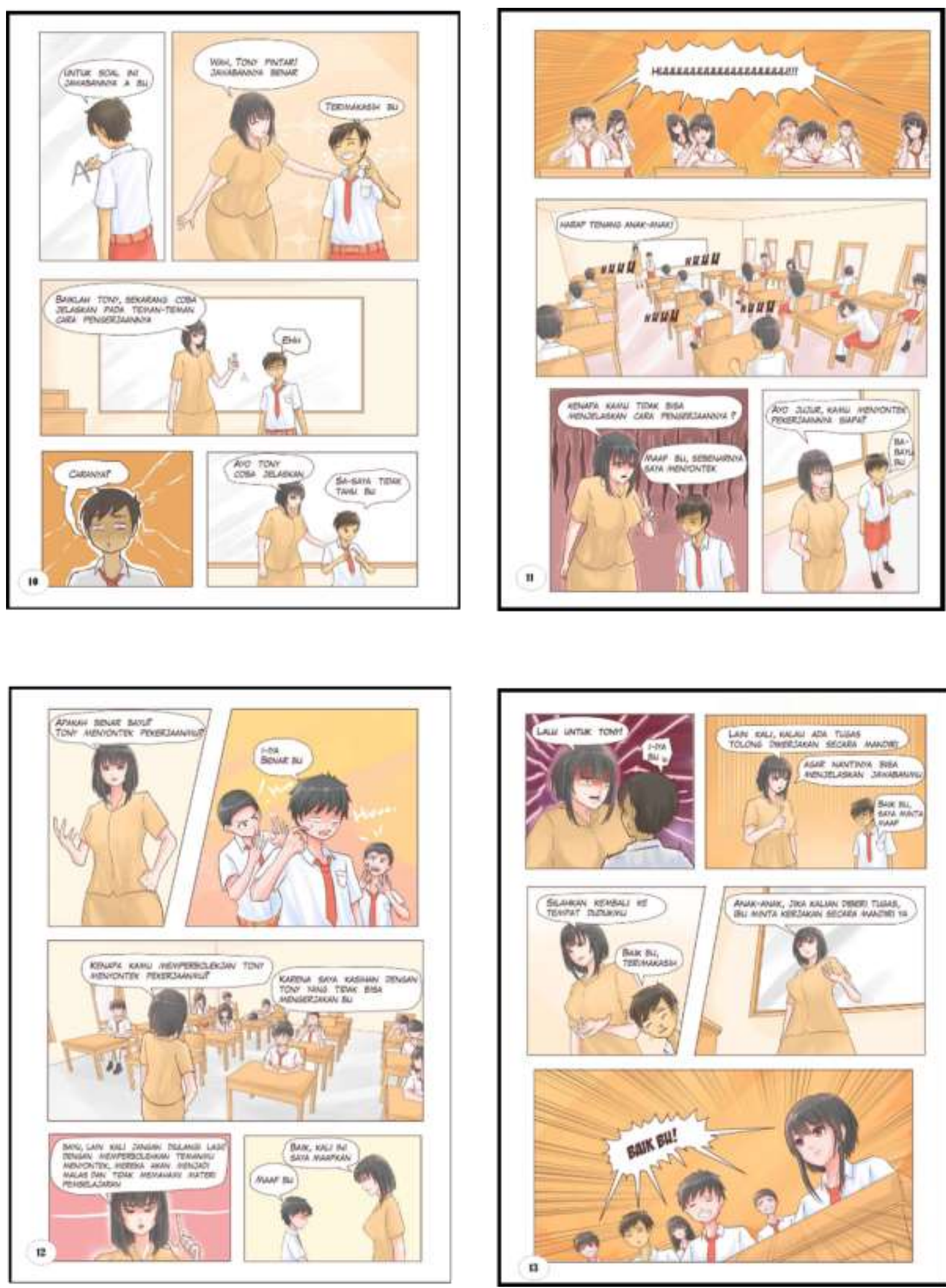

Belajar Siswa Sekolah Dasar-Susetyo Andri Wibowo, Henny Dewi Koeswanti DOI: https://doi.org/10.31004/basicedu.v5i6.1600
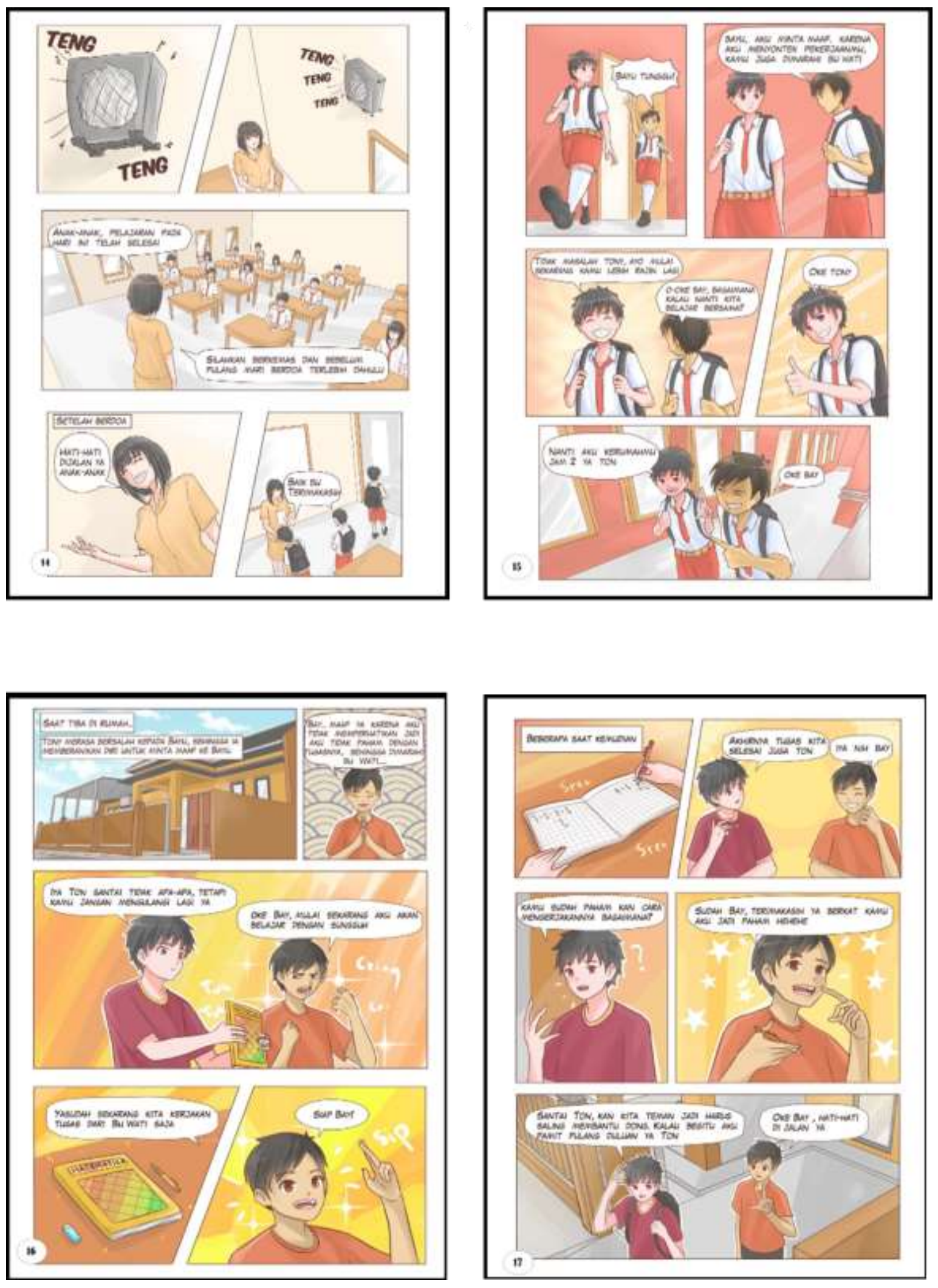

Belajar Siswa Sekolah Dasar-Susetyo Andri Wibowo, Henny Dewi Koeswanti

DOI: https://doi.org/10.31004/basicedu.v5i6.1600
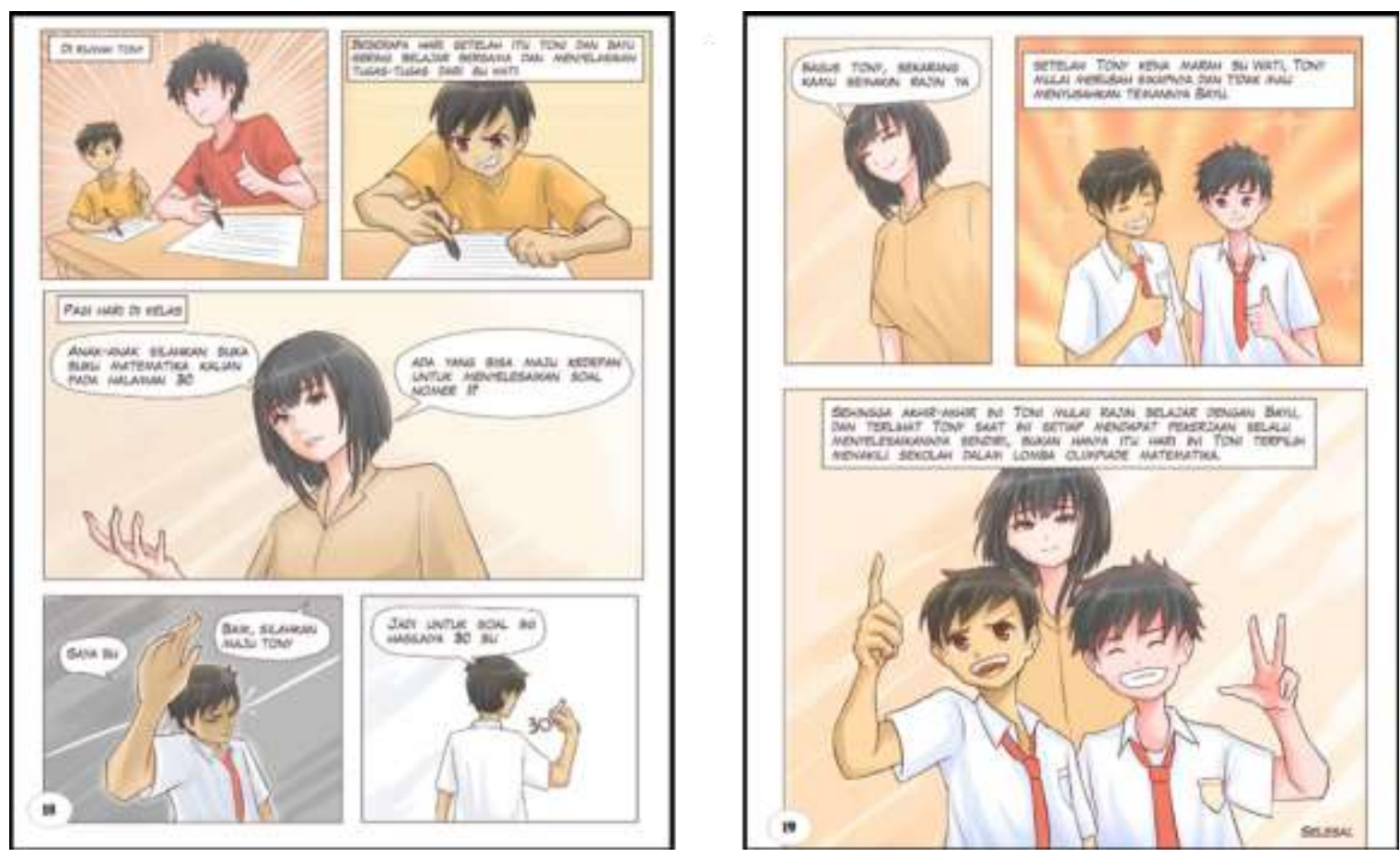

Gambar 2. Ilustrasi dan cerita tentang seorang anak yang tidak mandiri

Berdasarkan Gambar 2, diceritakan bahwa ada seorang anak bernama Tony. Disini Tony adalah seorang anak yang malas dalam mengerjakan tugas dari bu wati dan bergantung kepada Bayu temannya dalam mengerjakan tugas sehingga Tony tidak bisa mengerjakan tugasnya sendiri sehingga Tony dimarahi bu Wati karena tidak bisa mengerjakan tugasnya secara mandiri.

Tahap Pengembangan (Develop) pada tahap ini komik dilakukan tahap uji validasi kepada tiga ahli yaitu ahli media pembelajaran, ahli materi pembelajaran dan ahli bahasa. Dari tahap uji validasi oleh pakar diberikan saran perbaikan untuk penyempurnaan produk serta dilakukan tahap perbaikan media sesuai dengan saran yang diberikan oleh para ahli. Berikut hasil uji validasi dari ahli media pembelajaran, ahli materi pembelajaran dan ahli Bahasa pembelajaran.

Tabel 2. Hasil Uji Validasi

\begin{tabular}{|c|c|c|c|}
\hline Ahli & Aspek & Persentase & Kriteria \\
\hline \multirow[b]{2}{*}{ Media Pembelajaran } & Kualitas & \multirow[b]{2}{*}{$75 \%$} & \multirow[b]{2}{*}{ Tinggi } \\
\hline & Grafis & & \\
\hline \multirow{2}{*}{ Materi Pembelajaran } & Kualitas & \multirow{2}{*}{$71 \%$} & \multirow{2}{*}{ Tinggi } \\
\hline & Grafis & & \\
\hline \multirow{2}{*}{ Bahasa Pembelajaran } & Kualitas & \multirow{2}{*}{$75 \%$} & \multirow{2}{*}{ Tinggi } \\
\hline & Grafis & & \\
\hline
\end{tabular}

Dari tabel diatas dapat disimpulkan bahwa berdasarkan penilaian uji validasi ahli media belajar diperoleh nilai sebesar $75 \%$, yang artinya bahwa media komik untuk meningkatkan belajar siswa siswa kelas 3 SD dikategorikan tinggi dan layak untuk digunakan. Aspek yang divalidasi meliputi aspek kualitas yang meliputi kualitas gambar yang digunakan dalam komik, desain sampul menarik minat pembaca, isi komik disajikan secara runtut, alur cerita mudah dipahami, alur cerita dalam komik menarik, keteraturan design halaman komik, kesesuaian cerita, gambar, dan materi, ketepatan penggunaan kalimat. Aspek kedua yaitu 
5111 Pengembangan Media Pembelajaran Berbasis Komik untuk Meningkatkan Karakter kemandirian Belajar Siswa Sekolah Dasar- Susetyo Andri Wibowo, Henny Dewi Koeswanti

DOI: https://doi.org/10.31004/basicedu.v5i6.1600

grafis, yang terdiri dari pemilihan jenis dan ukuran huruf mudah dibaca dan komik menjadi lebih menarik, pemilihan warna, lay out gambar dan teks dan cover komik terlihat menarik

Sementara itu berdasarkan penilaian uji validasi ahli materi belajar diperoleh nilai sebesar $71 \%$, yang artinya bahwa media komik untuk meningkatkan belajar siswa siswa kelas 3 SD dikategorikan tinggi dan layak untuk digunakan. Aspek yang divalidasi meliputi aspek kualitas yang meliputi kesesuaian isi dari sudut pandang disiplin ilmu, konsep yang digunakan baik, isi komik dapat memberikan pengetahuan baru, contoh dan kasus yang disajikan sesuai dengan situasi serta kondisi yang terjadi dalam kehidupan sehari-hari, informasi sesuai dengan perkembangan zaman, kesesuaian contoh dengan materi, evaluasi yang di gunakan baik untuk menguji kemampuan peserta didik, media pembelajaran komik sesuai dengan kebutuhan peserta didik. Sedangkan aspek yang kedua yaitu grafis yang terdiri dari pemilihan jenis dan ukuran huruf mudah dibaca dan komik menjadi lebih menarik, pemilihan warna, lay out gambar dan teks dan cover komik terlihat menarik.

Penilaian uji validasi oleh ahli bahasa diperoleh nilai sebesar $75 \%$, yang artinya bahwa media komik untuk meningkatkan belajar siswa siswa kelas 3 SD dikategorikan tinggi dan layak untuk digunakan. Aspek yang divalidasi meliputi aspek kualitas yang meliputi bahasa yang digunakan komunikatif, kalimat yang digunakan jelas (tidak menimbulkan makna ganda), kalimat yang digunakan sederhana (mudah dipahami), konsistensi penggunaan istilah, simbol, nama ilmiah/bahasa asing. Sedangkan aspek yang kedua yaitu grafis yang terdiri dari pemilihan jenis dan ukuran huruf mudah dibaca dan komik menjadi lebih menarik, pemilihan warna, lay out gambar dan teks dan cover komik terlihat menarik.

Seturut dengan pendapat (Handayani, 2020) pengembangan media komuk untuk meningkatkan minat baca siswa sekolah dasar dapat membantu siswa dalam meningkatkan minat baca siswa karena dengan disajikan sebuah gambar yang menarik dapat menghidupkan deretan teks tertulis yang menyertainya sehingga siswa akan lebih senang dalam membaca cerita pada komik.

Sependapat dengan penelitian (Sari, 2018) media komik dan kartu disiplin yang digunakan sebagai media pembelajaran siswa ini memiliki suatu kelebihan yaitu siswa dapat belajar mandiri, menguatkan pengertian, dan ingatan pada nilai-nilai karakter, karena dengan disajikan sebuah media yang dapat menarik perhatian siswa maka siswa akan antusias mencari tahu isi dari komik yeng dikembangkan. Sehingga secara berproses maksud dari dalam komik akan tertuang kepada setiap pembaca khususnya siswa kelas 3 SD.

\section{KESIMPULAN}

Penelitian ini menghasilkan sebuah media pembelajaran khususnya untuk meningkatkan kemandirian belajar siswa kelas 3 SD dengan sebuah komik. Pengembangan media komik belajar ini melalui tahap pendefinisian (define), perancangan (design), dan pengembangan (develop). Berdasarkan hasil validitas produk oleh ahli media, ahli materi dan ahli bahasa dikatakan layak digunakan sebagai media pembelajaran untuk meningkatkan karakter kemandirian belajar pada siswa kelas 3 Sekolah Dasar. Dikatakan layak digunakan karena pada uji validasi ahli media mendapat presentase $75 \%$, ahli materi mendapat presentase sebesar $71 \%$ dan mendapat presentase $75 \%$ dari hasil uji validasi ahli bahasa, ketiga hasil validasi tersebut termasuk dalam kategori tinggi.

\section{DAFTAR PUSTAKA}

Ariah. (2015). Pembentukan Karakter Kemandirian Siswa Melalui Implementasi Islamic Full Day School. Didaktika Tauhidi, 2, 122.

Cahyaningrum, E. S. (2017). Pengembangan Nilai-Nilai Karakter Anak Usia Dini Melalui Pembiasaan Dan Keteladanan. Universitas Negeri Yogyakarta, 6. 
5112 Pengembangan Media Pembelajaran Berbasis Komik untuk Meningkatkan Karakter kemandirian Belajar Siswa Sekolah Dasar-Susetyo Andri Wibowo, Henny Dewi Koeswanti

DOI: https://doi.org/10.31004/basicedu.v5i6.1600

Fadillah, A. (2018). Pengembangan Media Belajar Komik Terhadap Motivasi Belajar Siswa. Jtam | Jurnal Teori Dan Aplikasi Matematika, 2(1), 36.

Handayani, P. (2020). Pengembangan Media Komik Untuk Meningkatkan Minat Membaca Siswa Sekolah Dasar. Jurnal Basicedu, 4.

Herliana, S., \& Anugraheni, I. (2020). Pengembangan Media Pembelajaran Kereta Membaca Berbasis Kontekstual Learning Siswa Sekolah Dasar. Jurnal Basicedu, 4(2), 314-326.

Khairi, A. (2016). Pengembangan Media Komik Berbasis Karakter Untuk Siswa Sekolah Dasar. Jurnal Ppkn \& Hukum, 11(1), 98-110.

Lestari, A., \& Mustika, D. (2021). Analisis Program Pelaksanaan Penguatan Pendidikan Karakter (Ppk) Di Sekolah Dasar. Jurnal Basicedu, 5(3), 1577-1583.

Marsiyah, \& T. H. (2020). Implementasi Pembentukan Karakter Kemandirian Siswa Melalui Pembelajaran Kewirausahaan. Jurnal Dinamika Pendidikan, $13(3), \quad 352-360$. Https://Doi.Org/10.33541/Jdp.V12i3.1295

Mawardi. (2014). Model Desain Pembelajaran Konsep Dasar Pkn Berbasis Belajar Mandiri Menggunakan Moodle. Widya Sari Press Salatiga.

Nasution, T. (2018). Membangun Kemandirian Siswa Melalui Pendidikan Karakter. Jurnal Uinsu, 2.

Putry, R. (2019). Nilai Pendidikan Karakter Anak Di Sekolah Perspektif Kemendiknas. Gender Equality: International Journal Of Child And Gender Studies, 4(1), 39-54.

Rahmayani, F. (2019). Hubungan Antara Karakter Mandiri Belajar Dengan Hasil Belajar Siswa. Jpe (Jurnal Pendidikan Edutama), 6(2), 87-94.

Saputri, R. M. (2021). Pengembangan Buku Kumpulan Ceritabergambar Berbasis Pendidikan Karakter Di Sekolah Dasar. Basicedu, 5, 2586.

Sari, A. L. (2018). Pengembangan Media Komik Dan Kartu Disiplin Pada Pembelajaran Karakter Tema 6 Kelas Iii Sekolah Dasar Negeri Salatiga 9. Jurnal Widyagogik, 5, 111-121.

Silawati, Taat Kurnita Yeniningsih, D. A. (2021). Pengembangan Media Activity Book Untuk Meningkatkan Nilai Karakter Mandiri Anak Usia Dini Silawatil), . 6(2).

Subroto, E. N., Qohar, A., \& Dwiyana, D. (2020). Efektivitas Pemanfaatan Komik Sebagai Media Pembelajaran Matematika. Jurnal Pendidikan: Teori, Penelitian, Dan Pengembangan, 5(2), 135.

Sukmadinata. (2016). Metode Penelitian Pendidikan. Rosdakarya.

Suwarti, S., Laila, A., \& Permana, E. P. (2020). Pengembangan Media Komik Berbasis Kearifan Lokal Untuk Menentukan Pesan Dalam Dongeng Pada Siswa Sekolah Dasar. Profesi Pendidikan Dasar, 7(2), 140 151.

Wuryandani, W., Fathurrohman, F., \& Ambarwati, U. (2016). Implementasi Pendidikan Karakter Kemandirian Di Muhammadiyah Boarding School. Jurnal Cakrawala Pendidikan, 15(2), 208-216.

Yusutria, Y., \& Febriana, R. (2019). Aktualisasi Nilai-Nilai Kemandirian Dalam Membentuk Karakter Mandiri Siswa. Ta'dib: Jurnal Pendidikan Islam, 8(1), 577-582. 